\title{
Rheology of plasticized polymer solutions
}

SAIDE O. UMEROVA - Frantsevich Institute for Problems of Materials Science of NASU - SaideshaShine@mail.ru

IRYNA O. DULINA - Frantsevich Institute for Problems of Materials Science of NASU • i_risha@online.ua ANDReY V. RAGULYA - Frantsevich Institute for Problems of Materials Science of NASU

- ragulya@ipms.kiev.ua

Érkezett: 2015. 07. 08. - Received: 08. 07. 2015. - http://dx.doi.org/10.14382/epitoanyag-jsbcm.2015.19

Saide Oleksandrivna UMEROVA postgraduate student. Leading engineer of Department of Physics, Chemistry and Technology of Nanotextured Ceramics and Nanocomposite Materials of Frantsevich Institute for Problems of Materials Science of NASU;

\section{Abstract}

This paper is about rheological properties of plasticized polymer solutions with different concentration of plasticizer. It was established that the investigated polymer solutions were threedimensionally structured systems which were shear thickened at low shear rates and maintained the thixotropic structural state under high shear rates. However, addition of different amount of plasticizer had an ambiguous influence on rheology of solutions and led to formation of transient polymer network with a complicated character of structuration because of the features of interaction in the polymer - plasticizer system. It was found that the plasticization results in changing of EC molecules conformation and simultaneous breaking of the polymer continuity due to DBP adsorption on EC macromolecule. Herewith, the formation of smaller crystallites took place. Besides, the investigated solutions showed causal link between structural states.

Keywords: rheology, polymer, rheopexy, pseudoplasticity, thixotropy

Kulcsszavak: reológia, polimer, reopexia, pszeudoképlékenység, tixotrópia

\section{Introduction}

Rheological behavior of concentrated suspensions is an important area of research because it provides rich information, concerning flow and storage of relevant materials under operation conditions. There are many publications focusing on rheology of polymer concentrated suspensions filled with metal oxide powders of various particle diameters. The rheological properties depend on the solid phase concentration [1-3], particle size[2, 4-6], concentration and molecular weight of polymer [1-3, 5-7] and also interaction between particles, solvent and polymer molecules $[2,5,9]$. Because of rapid development of microelectronics, the suspensions based on nanopowders represent the most promising objects for rheological investigations. Herewith, nanosized particles allow obtaining green ceramic layers with thickness of 700 to $800 \mathrm{~nm}$ and surface parameter Ra commensurable with size of nanoparticle [10].

It is known that screen printing pastes based on micron powders are generally required to be shear thinning, thixotropic over definite time scale and shear rate, stable for screen/shelflife and low solvent evaporation [11-13]. Therefore, terpineol [14-21] and its derivatives [17, 20, 22-25, 26-29] are used as a solvent, ethylcellulose as an organic binder [14, 15-21, 3042] because of their ability to form thixotropic systems with suspensions of particles of various origination [43]. However, there is almost no information about rheology of ethyl cellulose solutions in terpineol with the exception of [44]. In turn, it is the main factor that reflects structural features of polymer and determines degree of interaction with surface of solid particles.

In this work, the dependence of the rheological properties of ethyl cellulose (EC) solutions in terpineol (Terp) on plasticizer dibutyl phthalate (DBP) content has been studied to improve elastic properties of polymer, pastes and films based on them [45-53]. In general, the plasticization leads to decreasing the glass transition temperature, fluidity and improving the mechanical properties due to reduced interaction between macromolecules and mobility of enhanced segments [54-58]. Normally, plasticization implies great change of structuralmechanical properties $[55,58,59]$ due to interaction features in polymer - plasticizer system. The polymer macromolecule conformation and flow character of the appropriate solution are changing. Plasticizer influence, however, is not limited by rearrangement inside the $\mathrm{EC}$ molecule. $\mathrm{EC}$ is a rigid-chain polymer peculiar to polymorphism [60-62] - it forms individual crystallites in the form of packed antiparallel separate segments of macromolecule [63-65]. According to that, the DBP concentration should affect the polymer crystallization rate due to molecule re-conformation.

Therefore, this paper is about the features of viscosity and rheological behavior in the EC-DBF polymer systems depending on DBP concentration.

\section{Materials and methods}

Investigated solutions were prepared under heating and permanent stirring conditions. Terpineol was used as a solvent (mixture of $\alpha$ - and $\beta$-terpineol isomers, Merck $\mathrm{GmbH}$ ) forethyl cellulose $(10 \mathrm{cP}$, Merck $\mathrm{GmbH})$ as an organic binder and dibutyl phthalate (Merck $\mathrm{GmbH}$ ) as a plasticizer.

The rheological tests of the solutions has been carried out using rotary rheometer Rheotest RN4.1, Medingen at shear stresses from 1 to $1000 \mathrm{~Pa}$ and gap between coaxial cylinders of $1.48 \mathrm{~mm}$. All measurements were carried out at $20 \pm 0.5^{\circ} \mathrm{C}$. Herewith, the variable was DBP concentration in the solutions (changing from 0 to $40 \mathrm{~m} \%$ ).

Thixotropy and rheopexy degrees were determined from the hysteresis loop areas between up- and down-curves. In turn, the hysteresis loop area has a dimensionality of energy, correlated to sheared volume and determines the value of energy consumed for disrupting of thixotropic (rheopexic) structure [66]. 
A criterion of equilibrium degree of structure destruction (EDSD) for effective viscosity is determined as follows:

$$
\operatorname{EDSD}=\frac{\eta_{\text {мax }}-\eta_{\tau}}{\eta_{\text {мax }}-\eta_{\infty}}
$$

where $\eta_{\tau^{-}}$is the effective viscosity at given shear stress; $\eta_{\max }-$ is a maximal viscosity corresponding to nonvolatile initial structure; $-\eta_{\infty}$ is the less viscosity, corresponding to breaking point [67]. When EDSD $<1$ the recovery processes prevail destruction processes and vice-versa when EDSD $>1$.

Dilatancy degree $\mathrm{D}$ is characterized by the strength of sheared initial structure [68] and determined as:

$$
\mathrm{D}=\frac{\eta_{\mathrm{max}}-\eta_{\tau}}{\eta_{\tau}}
$$

where $\eta_{\text {мах }}-$ is the maximal viscosity corresponding to nonvolatile initial structure; $\eta_{\tau}$ - is the effective viscosity at given shear stress.

\section{Results and discussion}

\subsection{Rheology of initial polymer solution EC+Terp}

Fig. 1 shows viscosity profiles of EC+Terp solution PP1. Significant difference between up-curve and down-curve suggests PP1 as structurized polymer system with complicated flow due to the presence of two hysteresis loops. Accorging to the hysteresis loop in Fig. 1 a rheopexic structure is undegone destruction at shear stresses $0.1-407$ Pa. Further shearing has led to pseudoplastic flow region reflected in superposition of up-curve and down-curve. Above $483 \mathrm{~Pa}$ the system becomes thixotropic. Herewith, the thixotropy degree $\mathrm{T}$ is almost equal to the rheopexy degree $\mathrm{R}$ (Table 1). In turn, such a structural transition could be explained as follows. It is known that polymer solution represents three-dimension amorphous-crystalline system with high elastic properties [66, 69-71]. But individual molecules, their segments and microfibrils look spherical-shape coils and are in Brownian motion. When the system is undergone to low shearing, the elastic deformation of the initial network takes place: the coils partially overlap and form molecular linkage. This process is manifested in shear thickening region on viscosity profile (Fig. 1) and corresponds to dilatant properties of the system. Thus, the shear rate region where the viscosity increases is named an interval of structure reinforcement and formation; and Vd value corresponds to yield stress of initial structure. Herewith, the system shears like individual unit. According to the flow curves (Fig. 1), the beginning of initial structure damage is expressed in the rheopexic hystersis loop. Further shearing above Vd led to pseudoplastic flow region due to disrupting of cross links and transition to the regime of layered flow [72]. In the pseudoplastic region, the system is in equilibrium state because of balance between recovery and destruction processes. Further increased shear deformation leads to difference in shear rates between longitudinal molecular layers and the regions of intermolecular bonds appear. Co-existing of molecular associates with multiple bonds which can deform elastically so that the instantaneous local bonding is possible. Besides viscosity decreasing takes place due to thixotropy.
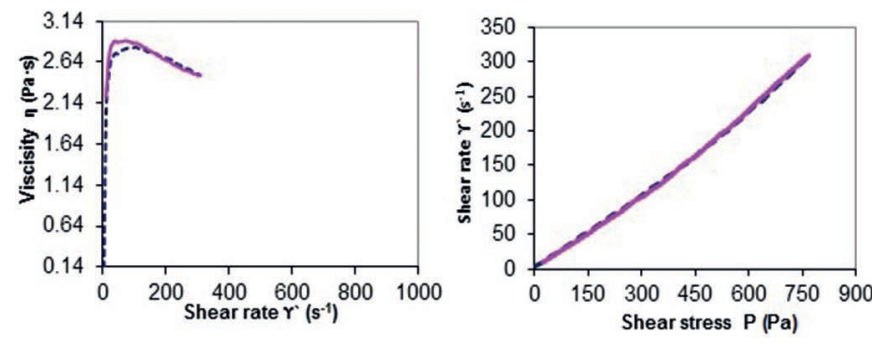

Fig. 1 Viscosity profiles and flow curves of PP1 sample

1. ábra Viszkozitási profilok és folyási görbék a PP1 jelü mintánál

\subsection{Rheology of plasticized polymer solutions}

In general, different concentration of DBP has an ambiguous influence on rheological properties of plasticized solutions and leads to various character of structuration. It was found that all solutions have thixotropic structural state and were shear thickened at low shear rates (Table 1).

Addition of 3.75, 5, 8.75, 17.5, 18.75, 20.8, 22.5, 25 and $30 \mathrm{~m} \%$ of DBP resulted information of system structuring similarly to PP1. Fig. 2 shows that the solutions PP3, PP4, PP6, PP11, PP12, PP14, PP16, PP17 and PP18 were successively in three structural states - rheopexic, pseudoplastic and thixotropic. The presence of plasticizer has led to viscosity $\eta_{\tau}$ decreasing. At the same time, for the sample PP14, increase of the viscosity value from 2.11 to $2.13 \mathrm{~Pa} \cdot \mathrm{s}$ was observed. Moreover, the DBP gives the Vd mean value of $25-30 \mathrm{~s}^{-1}$ (Table 1). It was also found that for the plasticized solutions with three structural states, the strength can be determined by thixotropy degree (Fig. 3). The increasing of $\mathrm{T}$ from 0.000001 to $0.0016 \mathrm{MPa} / \mathrm{s}$ almost does not affect the systems strength but further $\mathrm{T}$ rising to 0.006 $\mathrm{MPa} / \mathrm{s}$ has led to abrupt lowering of strength and decreasing of viscosity $\eta_{\tau}$ almost by four times (PP16, $22.5 \mathrm{~m} \%$ of DBP).

Discussed structural features could be explained as follows. The polymer systems with three structural states are disrupted thixotropic after passing through the previous states because of lower linearity and bigger size of polymer molecule and its similarity to a coil. Therefore, for the rheopexic and pseudoplastic states the orientation and layer-wise structural elements appear to be transformed to the thixotropic state.

It was established that addition of $2.5,10,11.25,12.5,20,21.7$ and $40 \mathrm{~m} \%$ of DBP resulted in thixotropic solutions (Fig. 4). The decrease of viscosity $\eta_{\tau}$ was observed as well. However, the presence of $10 \mathrm{~m} \%$ of plasticizer (PP7) increases viscosity $\eta_{\tau}$ from 2.11 up to $2.20 \mathrm{~Pa}$.s. In general, the plasticizing leads to Vd value growth in average $20-25 \mathrm{~s}^{-1}$ (Table 1). This structural state could be explained as follows. The thixotropy phenomenon means disrupting of initial three-dimensional network structure under increased shearing accompanied with viscosity decrease for entire range of applied shear rates [66]. In the case of PP2, PP7, PP8, PP9, PP13, PP15 and PP19 solutions, the disrupting of initial structure begins from Vd shear rate: i.e. the initial threedimensional structure after hardening within shear thickening region followed by two-dimensional layering in the Newtonian flow region $\Delta \mathrm{Vn}$, gradually transforms to the one-dimensional structure. The absence of rheopexy and pseudoplasticity can be explained by polymer texture originating from linearity of EC macromolecule adsorbing the DBP. Thus, the orientation of initial layered structure takes place due to shearing. 

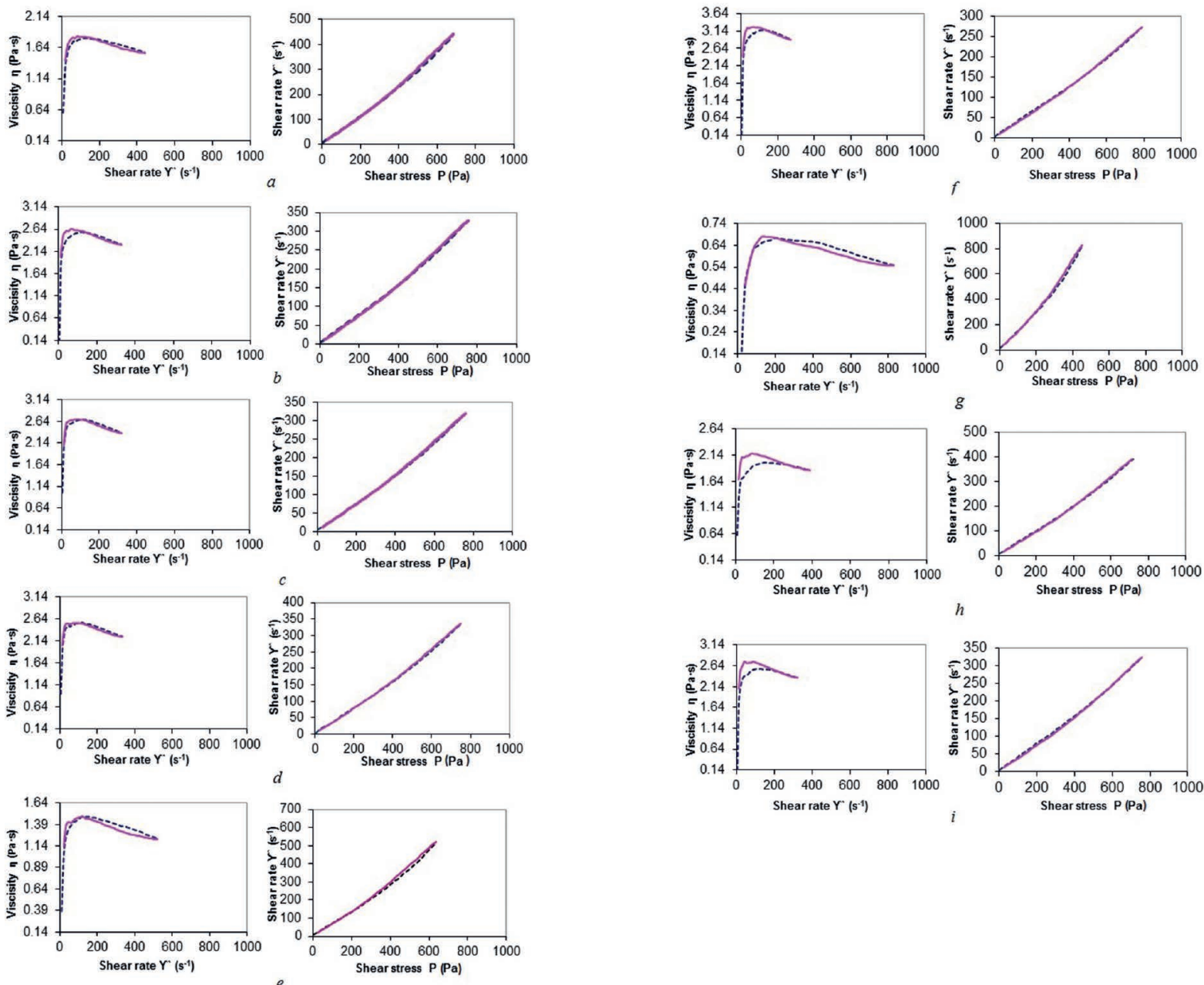

Fig. 2 Viscosity profiles and flow curves of plasticized solutions with three structural states (rheopexic, pseudoplastic and thixotropic)

2. ábra Viszkozitási profilok és folyási görbék a képlékenyitett oldatok három szerkezeti állapotára vonatkozóan (reopexikus, pszeudoplasztikus és tixotróp)

\begin{tabular}{|c|c|c|c|c|c|c|c|c|c|c|c|c|}
\hline $\begin{array}{l}\text { Solu- } \\
\text { tion }\end{array}$ & $\begin{array}{c}\text { DBP } \\
\text { content, } \\
\text { wt. } \%\end{array}$ & $\begin{array}{c}\text { Viscosity } \\
\eta_{\tau}, \mathrm{Pa} \cdot \mathrm{s}\end{array}$ & $\begin{array}{l}\text { Strenght } \\
\text { stress, } \\
\text { Pa }\end{array}$ & $\begin{array}{l}\text { Dilatent } \\
\text { flow Vd, } \\
\mathbf{s}^{-1}\end{array}$ & $\begin{array}{l}\text { Maximal } \\
\text { viscosity } \\
\eta_{\max }, \mathrm{Pa} \cdot \mathrm{c}\end{array}$ & $\begin{array}{l}\text { Newtonian } \\
\text { flow end } \\
\mathrm{Vn}_{2}, \mathbf{s}^{-1}\end{array}$ & $\begin{array}{c}\text { Length of } \\
\text { Newtonian } \\
\text { region, } \Delta \mathbf{V n}, \mathbf{s}^{-1}\end{array}$ & $\begin{array}{c}\text { Thixotropy } \\
\text { degree T, } \\
\text { MPa/s }\end{array}$ & $\begin{array}{l}\text { Dilatancy } \\
\text { degree R, } \\
\text { r.u. }\end{array}$ & $\begin{array}{c}\text { Rheopexy } \\
\text { degree } R \text {, } \\
\text { MPa/s }\end{array}$ & $\begin{array}{c}\text { EDSD, } \\
\text { r.u. }\end{array}$ & $\begin{array}{c}\text { Pseudopla } \\
\text { stic flow start, } \\
\text { Pa }\end{array}$ \\
\hline PP1 & 0 & 2.11 & 766 & 78 & 2.81 & 108 & 30 & 0.001 & 0.33 & 0.001 & 2.12 & 407 \\
\hline PP2 & 2.5 & 1.44 & 694 & 108 & 1.96 & 129 & 21 & 0.006 & 0.36 & 0 & 1.58 & 0 \\
\hline PP3 & 3.75 & 1.33 & 686 & 117 & 1.79 & 139 & 22 & 0.003 & 0.35 & 0.001 & 2.00 & 305 \\
\hline PP4 & 5 & 1.83 & 753 & 109 & 2.58 & 130 & 21 & 0,001 & 0.41 & 0.001 & 2.68 & 363 \\
\hline PP5 & 7.5 & 1.53 & 717 & 121 & 2.12 & 148 & 28 & 0.004 & 0.39 & 0 & 2.19 & 25 \\
\hline PP6 & 8.75 & 2.07 & 759 & 106 & 2.68 & 144 & 38 & 0.002 & 0.29 & 0.000 & 2.03 & 242 \\
\hline PP7 & 10 & 2.20 & 784 & 103 & 3.19 & 117 & 14 & 0.004 & 0.45 & 0 & 2.54 & 0 \\
\hline PP8 & 11.25 & 1.05 & 595 & 116 & 1.40 & 130 & 14 & 0.012 & 0.33 & 0 & 0.92 & 0 \\
\hline PP9 & 12.5 & 1.29 & 649 & 99 & 1.68 & 123 & 24 & 0.011 & 0.30 & 0 & 1.05 & 0 \\
\hline PP10 & 15 & 1.46 & 732 & 172 & 2.18 & 189 & 17 & 0.000 & 0.49 & 0.003 & 4.50 & 0 \\
\hline PP11 & 17.5 & 1.91 & 750 & 86 & 2.54 & 127 & 41 & 0 & 0.33 & 0.000 & 2.17 & 261 \\
\hline PP12 & 18.75 & 1.08 & 636 & 136 & 1.46 & 162 & 26 & 0.006 & 0.35 & 0.000 & 1.65 & 164 \\
\hline PP13 & 20 & 1.59 & 709 & 108 & 2.15 & 127 & 19 & 0.010 & 0.35 & 0 & 1.40 & 0 \\
\hline PP14 & 20.8 & 2,13 & 789 & 130 & 3.18 & 0 & 0 & 0.001 & 0.49 & 0.001 & 3.75 & 435 \\
\hline PP15 & 21.7 & 1.05 & 684 & 100 & 1.92 & 132 & 33 & 0.010 & 0.83 & 0 & 2.35 & 0 \\
\hline PP16 & 22.5 & 0.46 & 453 & 198 & 0.67 & 0 & 0 & 0.006 & 0.48 & 0.000 & 1.75 & 134 \\
\hline PP17 & 25 & 1.40 & 718 & 146 & 2.00 & 165 & 19 & 0.000 & 0.43 & 0.004 & 4.00 & 538 \\
\hline PP18 & 30 & 1.82 & 757 & 109 & 2.57 & 133 & 25 & 0.000 & 0.41 & 0.002 & 3.41 & 535 \\
\hline PP19 & 40 & 1.88 & 744 & 77 & 2.53 & 110 & 33 & 0.004 & 0.35 & 0 & 1.86 & 0 \\
\hline
\end{tabular}

Table 1 Composition and rheological properties of two- and three-component polymer solutions

1. táblázat Két-és háromkomponensủ polimer oldatok összetétele és reológiai jellemzői 
The solution PP5 (7.5 m\% of DBP) was the polymer system with two structural states: in the range of shear strain of $25-$ $173 \mathrm{~Pa}$ the pseudoplastic flow has been observed and further shearing led the system to transform into thixotropical one (Fig. 5). In this case the plasticizer addition also led to viscosity $\eta_{\tau}$ decreasing from 2.11 to $1.53 \mathrm{~Pa} \cdot \mathrm{s}$ and $\mathrm{Vd}$ increasing up to $121 \mathrm{~s}^{-1}$ (Table 1).

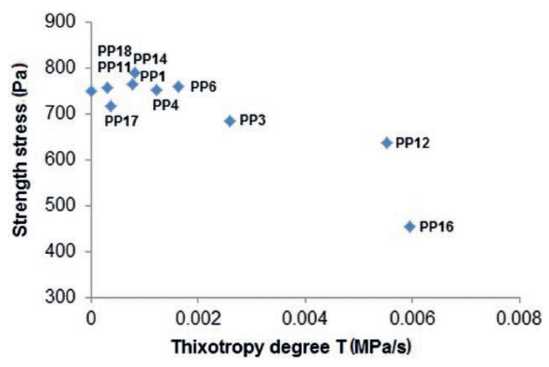

Fig. 3 Strength dependence of thixotropy degree for plasticized solutions with three structural states (rheopexic, pseudoplastic and thixotropic)

3. ábra Szilárdság függése a tixotrópia fokától a képlékenyitett oldatok három szerkezeti állapotára vonatkozóan (reopexikus, pszeudoplasztikus és tixotróp)

Addition of $15 \mathrm{~m} \%$ of DBP (PP10) corresponds to formation of two structural states in the system. In the shear stress range $25-520 \mathrm{~Pa}$ the solution was rheopexic but the further shearing up to $732 \mathrm{~Pa}$ forced the systems transform into thixotropical one and abide the pseudoplastic structural state (Fig. 6). The viscosity $\eta_{\tau}$ decreasing from 2.11 to $1.46 \mathrm{~Pa} \cdot \mathrm{s}$ and Vd increasing from 78 to $172 \mathrm{~s}^{-1}$ were observed (Table 1).

Understanding of whether the plasticizer provides one or several structural states during shearing needs to establish what the dissolved polymer is. It is known that polymer chains have some flexibility because of which macromolecules are folded $[55,73]$. Thus, polymer has loosen structure with large intermolecular voids (Fig. 7, 1st stage). On the first stage of dissolving the swelling of polymer takes place - solvent molecules diffuse into the polymer and fill the intermolecular voids. Further increasing of solvent volume leads to macromolecules moving apart because of changed gyration radius and distance between the centers of mass. Herewith, the continuity of polymer body is retained. However, an intensification of swelling leads to appearance of antiparallel separate segments of macromolecule referred as crystallites [74]. At the same time the crystallites exist in large quantities and alternating with amorphous regions form the center of elementary fibril [54] (Fig. 7, 3rd stage). The external part of elementary fibril is paracrystalline zone with large surface energy. Thus, elementary fibrils are prone to lateral aggregation with formation of fibrils (Fig. 7, 4th stage). But further stirring and, therefore, exceeding the optimal swelling time results in destruction of polymer continuity and molecules begin to tear off passing into the solution.

However, if plasticizer would be added before the final transition of polymer to the solution, the molecule conformation changes simultaneously with segments moving apart due to DBP adsorption on EC molecule [58] (Fig. 8, 2nd stage). Herewith the smaller crystallites are formed because of reducing the number of antiparallel macromolecule segments. Thus, the achieved plasticized solution will be predominantly
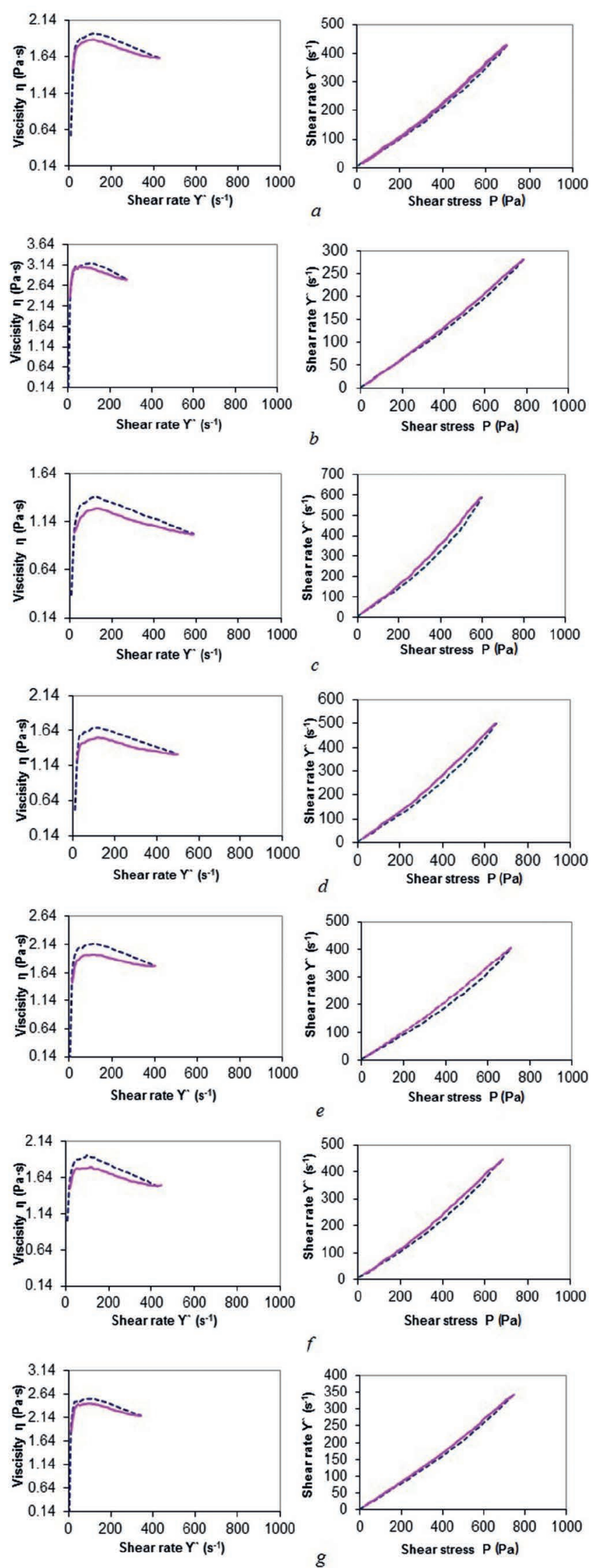

Fig. 4 Viscosity profiles and flow curves of plasticized solutions with thixotropic structural state

4. ábra Viszkozitási profilok és folyási görbék a képlékenyített oldatok tixotróp szerkezeti állapotára vonatkozóan 
amorphous system with some concentration of crystallites. But plasticizer addition does not exclude the possibility of EC macromolecule disrupting to smaller parts (Fig. 8, 3rd stage) on dissolving. The EC macromolecule has so-called weak points (authors of [55] assume the presence of leisure chains without hemiacetal bond $\mathrm{C}_{(1)} \rightarrow \mathrm{C}_{(5)}$ together with closed pyranose cycles).
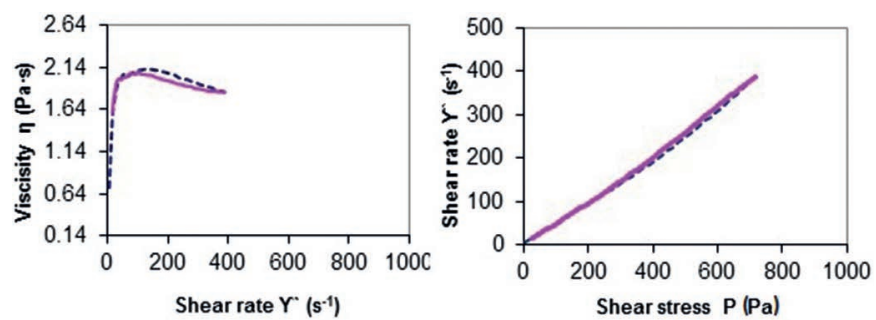

Fig. 5 Viscosity profile and flow curves of plasticized solution PP5 with pseudoplastic and thixotropic structural states

5. ábra Viszkozitási profil és folyási görbék a PP5 jelü képlékenyitett oldat pszeudoplasztikus és tixotróp szerkezeti állapotára vonatkozóan
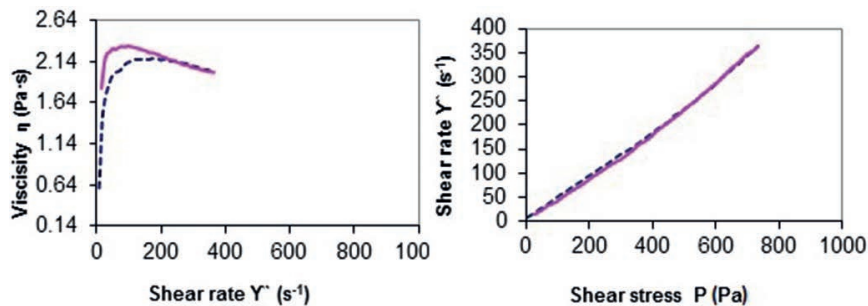

Fig. 6 Viscosity profile and flow curves of plasticized solution PP10 with rheopexic and thixotropic structural states

6. ábra Viszkozitási profil és folyási görbék a PP10 jelü képlékenyített oldat reopexikus és tixotróp szerkezeti állapotára vonatkozóan

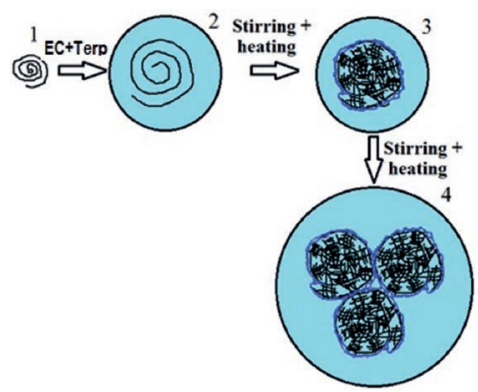

Fig. 7 Stages of interaction in the initial solution EC+Terp

7. ábra A kölcsönhatások szakaszai a kezdeti EC+Terp oldatban

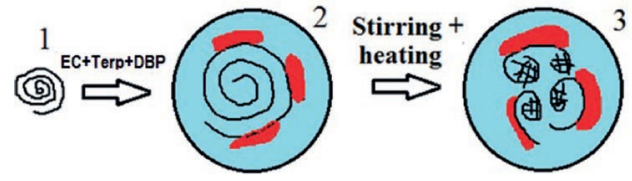

Fig. 8 Stages of interaction in plasticized solution $E C+$ Terp $+D B P$

8. ábra A kölcsönhatások szakaszai a képlékenyitett EC+Terp+DBP oldatban

So, plasticizer addition leads to formation of threedimensional structure with certain physical-mechanical properties as a result of plasticized EC macromolecule conformation. In general, the specific change of some rheological characteristics is comprehensive. In particular, Vd increases and $\eta_{\tau}$ decreases that is entirely consistent with features of structure formation during plasticizing. Formed small crystallites affect as particulate-reinforcing phase. The viscosity $\eta_{\tau}$ decreases due to lowering of strength stress of structure (Fig. 9). However, for PP16 (22.5 $\mathrm{m} \%$ of DBP) the viscosity $\eta_{\tau}$ decreases in almost 4 times because of the lowest strength value and possible bimodal distribution of crystallites [75].

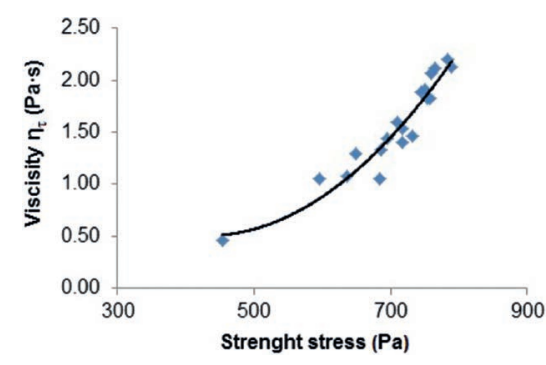

Fig. 9 Viscosity $\eta_{\tau}$ dependence on strength 9. ábra Viszkozitás $\eta_{\tau}$ szilárdságfüggése

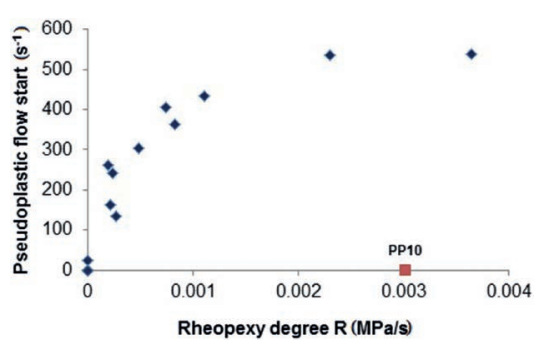

Fig. 10 Rheopexy degree versus pseudoplastic flow start 10. ábra Reopexikusság foka és pszeudoplasztikus folyás kezdete

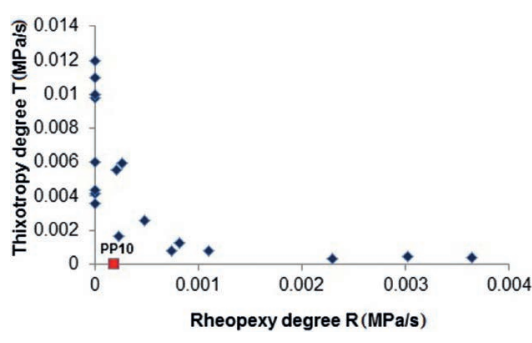

Fig. 11 Rheopexy degree versus thixotropy degree 11. ábra Reopexikusság foka és tixotrópia foka

It was established that the investigated solutions demonstrate causal link between structural states formed. In particular, the rheopexy degree $\mathrm{R}$ determines the start of pseudoplastic flow and thixotropy degree T. Fig. 10 shows that the R increasing from 0 to $0.0015 \mathrm{MPa} / \mathrm{s}$ leads to pseudoplastic flow start at higher shear rates $\left(\sim 500 \mathrm{~s}^{-1}\right)$. But further increase in $\mathrm{R}$ does not effect on system transforming into two-dimensional state. Such a tendency was observed almost for all solutions (the PP10 was exception only because of absence of pseudoplastic flow region). In turn, the $\mathrm{R}$ value grows up to $0.0015 \mathrm{Mpa} / \mathrm{s}$ and leads to abrupt decrease in T. Further increase in $\mathrm{R}$ does not affect the system transforming into one-dimensional state. The only exception concerns the PP10 similarly to dependence shown in Fig. 10. In both cases, the PP10 exception can be explained as follows. Due to the fact that the initial structure of all the solutions is disrupted and restored under increased shear rates, it seems to be true that the thixotropy degree $\mathrm{T}$ decreases with increasing of the rheopexy degree R (Fig. 11). Besides, Table 1 shows that for the PP10 the EDSD criteria value is the highest one. Thus, in the PP10 case the destruction processes dominate over recovery processes without equilibrium state. 


\section{Conclusions}

The investigated polymer solutions were three-dimensional structured systems which were shear thickened at low shear rates and maintained the thixotropic structural state under high shear rates. It was found that the initial polymer solution EC+Terp was successively in three structural states: rheopexic, pseudoplastic and thixotropic. Herewith, the R was almost equal to $\mathrm{T}$ because of equal recovery and destruction processes. However, addition of different amount of plasticizer had an ambiguous influence on rheology of solutions and led to formation of transient polymer network with a complicated character of structuration because of the features of interaction in the polymer - plasticizer system. It was established that the plasticization results in changing of EC molecules conformation and simultaneous breaking of the polymer continuity due to DBP adsorption on EC macromolecule. Herewith, the formation of smaller crystallites took place. Besides, the investigated solutions showed causal link between structural states. In particular, the rheopexy degree $\mathrm{R}$ determines pseudoplastic flow start and the thixotropy degree $\mathrm{T}$.

\section{Acknowledgment}

Authors are grateful to the State Agency on Science Innovations and Informatization of Ukraine for a financial support for the project NN352-2012.

\section{References}

[1] Zupančič, A. - Lapasin, R. - Žumer, M. (1997): Rheological characterization of shear thickening $\mathrm{TiO}_{2}$ suspensions in low molecular polymer solution. Progress in organic coatings. Vol. 30. pp. 67 - 78. http://dx.doi.org/10.1016/S0300-9440(96)00670-4

[2] Kamibayashi, M. - Ogura, H. - Otsubo, Y. (2008): Shear thicknenig flow of nanoparticle suspensions flocculated by polymer bridging. Journal of Colloid and Interface Science. Vol. 321. pp. 294 - 301. http://dx.doi.org/10.1016/j.jcis.2008.02.022

[3] Otsubo, Y. (1990): Elastic percolation in suspensions flocculated by polymer bridging. Langmuir. Vol. 6. No. 1. pp. $114-118$. http://dx.doi.org/10.1021/la00091a016

[4] Fleer, G.J. - Lyklema, J. (1974): Polymer adsorption and its effect on the stability of hydrophobic colloids. Journal of Colloid and Interface Science. Vol. 46. No. 1. pp. 1 - 12. http://dx.doi.org/10.1016/0021-9797(74)90018-6

[5] Kamibayashi, M. - Ogura, H. - Otsubo, Y. (2006): Rheological behavior of suspensions of silica nanoparticles in associating polymer solutions. Ind. Eng. Chem. Res. Vol. 45. pp. 6899 - 6905. http://dx.doi.org/10.1021/ie0512486

[6] Otsubo, Y. (1986): Effect of polymer adsorption on the rheological behavior of silica suspensions. Journal of Colloid and Interface Science. Vol. 112. No. 2. pp. $380-386$. http://dx.doi.org/10.1016/0021-9797(86)90105-0

[7] Otsubo, Y. (1999): Rheological behavior of suspensions flocculated by weak bridging of polymer coils. Journal of Colloid and Interface Science. Vol. 215. pp. 99 - 105. http://dx.doi.org/10.1006/jcis.1999.6252

[8] Otsubo, Y. (1990): Rheological studies on bridging flocculation. Colloids and Surfaces. Vol. 50. pp. $341-352$. http://dx.doi.org/10.1016/0166-6622(90)80274-8

[9] Otsubo, Y. (1994): Relation between bridging conformation and rheology of suspensions. Advances in Colloid and Interface Science. Vol. 53. pp. 1 32. http://dx.doi.org/10.1016/0001-8686(94)00206-1

[10] Umerova, S. O. - Dulina, I. O. - Ragulya, A. V. (2014): Formation features of thin bilayer objects «conductor - dielectric» obtained by screen printing method. International conference "Nanomaterials: Application and properties". Lviv. $21-26$ of September 2014. Proceedings of Conferens. Vol. 1.pp. 01NTF04-1 - 01 NTF04-6.

[11] Lin, H.-W. - Chang, C.-P. - Hwu, W.-H. - Ger, M.-D. (2008): The rheological behaviors of screen-printing pastes. J. Mater. Process. Technol. Vol. 197. pp. 284 - 291. http://dx.doi.org/10.1016/j.jmatprotec.2007.06.067
[12] Vijatovic, M. M. - Bobic, J. D. - Stojanovic, B. D. - Malic, B. (2010): Barium titanate thick films prepared by screen printing technique. Process. Appl. Ceram. Vol. 4. No. 2. pp. 53 - 58. http://dx.doi.org/10.2298/PAC1002053V

[13] Phair, J. (2008): Rheological analysis of concentrated zirconia pastes with ethyl cellulose for screen printing SOFC electrolyte films. J. Am. Ceram. Soc. Vol. 91. pp. $2130-2137$. http://dx.doi.org/10.1111/j.1551-2916.2008.02443.x

[14] Wagiran, R. - Wan Zaki, W. S. - Mohd Noor, S. D. B. - Shaari, A. Y. Ahmad, I. (2005): Characterization of screen printed $\mathrm{BaTiO}_{3}$ thick film humidity sensor. Int. J. Eng. Technol. Vol. 2. No. 1. pp. $22-26$.

[15] Chen, Y - Gong, S.-P. - Li, H. - Wang, F.-J. - Yu, S.-J. - Xu, L.-F. (2007): $\mathrm{Ni}-\mathrm{BaTiO}_{3}$ interface phenomenon of Co-fired PTCR by aqueous tape casting. J. Nonferr. Metal. Soc. Vol. 17. pp. 1391-1395. http://dx.doi.org/10.1016/S1003-6326(07)60283-0

[16] Pat. 6.454.830 B1 US. Int. CI. B22F 1/00. Nickel powder for multilayer ceramic capacitors / T. Ito (JP). H. Takatori (JP); assignee Toho Titanium Co., Ltd. (JP). - Appl. No. 09/786.032; filed 09.04.2001; publicised 24.09.2002. $-8 \mathrm{p}$.

[17] Pat. 2002/0189402 A1 US. Int. CI.B22F 9/22. Nickel powder dispersion. method of producing nickel powder dispersion and method of producing conductive paste / T. Ito(JP). H. Takatori (JP). - Appl. No. 09/937.689; filed 28.09.2001; publicised 19.12.2002. - $12 \mathrm{p}$.

[18] Im, D.-H. - Hyun, S.-H. - Park, S.-Y. - Lee, B-Y. - Kim, Y.-H. (2006): Preparation of Ni paste using binary powder mixture for thick film electrodes. Mater. Chem. Phys. Vol. 96. pp. 228-233. http://dx.doi.org/10.1016/j.matchemphys.2005.07.047

[19] Pat. 2011/0141654 A1 US. Int. CI. H01G 4/30 (2006.01). B22F 1/00 (2006.01). B01B 1/22 (2006.01). C22C 19/03 (2006.01). Nickel powder or alloy powder. comprising nickel as main component. method for producing the same. conductive paste and laminated ceramic capasitor / I. Okada (JP); assignee Sumitomo electric industries. Ltd. (JP). - Appl. No. 13/059.323; filed 26.07.2009; publicised 16.06.2011. - 12 p.

[20] Pat. 2007/0108419 A1 US. Int. CI. H05K 3/00 (2006.01). H01B 1/12 (2006.01). Conductive paste for an electrode layer of a multi-layered ceramic electronic component and a method for manufacturing a multilayered unit for a multi-layered ceramic electronic component / S. Satou. T. Nomura (JP); assignee TDK Corporation (JP). - Appl. No. 10/580.991; filed 24.11.2004; publicised 17.06.2007. $-21 \mathrm{p}$.

[21] Pat. 2010/0208410 A1 US. Int. CI. H01G 4/008 (2006.01). C22C 19/03 (2006.01). B22F 9/16 (2006.01). H01B 1/02 (2006.01). Nickel powder or alloy powder. having nickel as main component. method for manufacturing the powder. conductive paste and laminated ceramic capasitor / I. Okada (JP). K. Koyama (JP). - Appl. No. 12/678.684; filed 09.07.2008; publicised 19.08.2010. - $10 \mathrm{p}$

[22] Pat. 2012/0048452 B2 US. Int. CI. C04B 35/64 (2006.01). B32B 37/02 (2006.01). C04B 35/622 (2006.01). Method of manufacturing ceramic paste for multilayer ceramic electronic component and method of manufacturing multilayer ceramic electronic component having the same / J.M. Suh (KR). W.S. Choi (KR). J.H. Bae (KR). H. Kim (KR); assignee Samsung Elecro-Mechnics Co., LTD (KR). - Appl. No. 13/191.053; filed 26.07.2011; publicised 01.03.2012. $-6 \mathrm{p}$.

[23] Pat. 2012/0147514 A1 US. Int. CI. H01G 4/30 (2006.01). B32B 37/06 (2006.01). B32B 37/14 (2006.01). C04B 35/00 (2006.01). B32B 37/02 (2006.01). Ceramic paste composition for multilayer ceramic capacitor. multilayer ceramic capacitor comprising the same and methods of manufacturing the same / J.M. Suh (KR). H. Kim (KR). H. Lee (KR); assignee Samsung Elecro-Mechnics Co., LTD (KR). - Appl. No. 13/116.526; filed 26.06.2011; publicised 14.06.2012. -6 p.

[24] Pat. 2002/0047109 A1 US. Int. CI. H01B 1/00. H01C 1/00. Conductive paste/ H. Yoshida (JP). T. Endo (JP). M. Mori (JP). - Appl. No. 9/923.056; filed 06.08.2001; publicised 25.04.2002. $-6 \mathrm{p}$.

[25] Pat. 2007/0012899 A1 US. Int. CI. H01B 1/12 (2006.01). Phoshate dispersant. paste composition and dispersion method using the same / E.-S. Lee. J.-Y. Choi. S.-M. Yoon. S.-K. Kim. J.-H. Kim. J.-G. Baek. (KR); assignee Samsung Electro-Mechanies Co., Ltd (KR). - Appl. No. 11/319.448; filed 29.12.2005; publicised 18.01.2007. - $12 \mathrm{p}$.

[26] Pat. 2009/0032780 A1 US. Int. CI. H01B 1/02 (2006.01). Nickel paste / T. Suglyama (JP); assignee Noritake Co., Limited (JP). - Appl. No. 12/219.828; filed 29.07.2008; publicised 05.12.2009. - 9 p.

[27] Pat. 2010/0038604 A1 US. Int. CI. H01B 1/22 (2006.01). Nickel paste / T. Suglyama (JP); assignee Noritake Co., Limited (JP). - Appl. No. 12/546.495; filed 24.08.2009; publicised 18.02.2010. - 9 p. 
[28] Pat. 7.463.477 B2 US. Int. CI. H01G 4/06 (2006.01). Multilayer ceramic electronic part and conductive paste / S.-M. Yoon. E.-S. Lee. J.-Y. Choi. S.K. Kim. J.-G. Baek. S.-H. Lee (KR); assignee Samsung Electro-Mechanies Co., Ltd (KR). - Appl. No. 11/318.558; filed 28.12.2005; publicised 09.12.2008. - $16 \mathrm{p}$.

[29] Pat. 2007/0014074 A1 US. Int. CI. H01G 4/008 (2006.01). Mixed dispersant. paste composition and dispersion method using the same / S.-M. Yoon. E.-S. Lee. J.-Y. Choi. S.-K. Kim. J.-G. Baek. S.-H. Lee (KR); assignee Samsung Electro-Mechanies Co., Ltd (KR). - Appl. No. 11/318.558; filed 28.12.2005; publicised 18.01.2007. - $16 \mathrm{p}$.

[30] Leppavuori, S. - Uusimaki, A. - Hannula, T. (1981): Electrical properties of thick film capacitors based on barium titanate glass formulations. Thin Solid Films. Vol. 86. pp. 287-295. http://dx.doi.org/10.1016/0040-6090(81)90336-9

[31] Pat. 6.366.444 B1 US. Int. CI. H01G 4/06. Multilayer ceramic electronic part and conductive paste / J. Yagi (JP); assignee Taiyo Yuden Co., Ltd. (JP). Appl. No. 09/537.979; filed 30.03.2000; publicised 02.04.2002. - 11 p.

[32] Pat. 6.551.527 B2 US. Int. CI. H01B 1/22. Conductive paste comprising N-acylamino acid/ H. Yoshida (JP). T. Endo (JP). M. Mori (JP); assignee Shoei Chemical Inc/ (JP). - Appl. No. 9/923.056; filed 06.08.2001; publicised 22.04.2003. - 5 p.

[33] Pat. 6.632.524 B1 US. Int. CI. H01B 1/02. Nickel powder. method for preparing the same and paste for use in making electrodes for electronic parts/ Y. Toshima (JP). T. Hayashi (JP). Y. Yamaguchi (JP). H. Shimamura (JP); assignee Mitsui Mining and Smelting Co., Ltd. (JP). - Appl. No. 09/716.238; filed 21.11.2000; publicised 14.10.2003. - 7 p.

[34] Pat. 6.454.830 B1 US. Int. CI. B22F 1/00. Nickel powder for multilayer ceramic capacitors / T. Ito (JP). H. Takatori (JP); assignee Toho Titanium Co., Ltd. (JP). - Appl. No. 09/786.032; filed 09.04.2001; publicised 24.09.2002. - 8 p.

[35] Pat. 6.632.265 B1 US. Int. CI. C22B 23/00. Nickel powder. method for preparation thereof and conductive paste/ T. Mukuno (JP). T. Araki (JP). Y. Toshima (JP); assignee Mitsui Mining and Smelting Co., Ltd. (JP). Appl. No. 09/869.970; filed 09.10.2001; publicised 14.10.2003. - 8 p.

[36] Pat. 6.494.941 B1 US. Int. CI. B22F 1/00. Nickel powder and conductive paste/ T. Mukuno (JP). T. Araki (JP). Y. Toshima (JP); assignee Mitsui Mining and Smelting Co., Ltd. (JP). - 2001Appl. No. 09/889.149; filed 10.11.2000; publicised 17.12.2002. $-8 \mathrm{p}$.

[37] Pat. 2001/0013263 A1 US. Int. CI. B22F 1/00. Nickel powder and conductive paste/ Y. Yamaguchi (JP). T. Hayashi (JP); assignee Mitsui Mining and Smelting Co., Ltd. (JP). - Appl. No. 09/773.908; filed 02.02.; publicised 16.08.2001. - 5 p.

[38] Pat. 2007/0012899 A1 US. Int. CI. H01B 1/12 (2006.01). Phoshate dispersant. paste composition and dispersion method using the same / E.-S. Lee. J.-Y. Choi. S.-M. Yoon. S.-K. Kim. J.-H. Kim. J.-G. Baek. (KR); assignee Samsung Electro-Mechanies Co., Ltd (KR). - Appl. No. 11/319.448; filed 29.12.2005; publicised 18.01.2007. - 12 p.

[39] Pat. 6.548.437 B2 US. Int. CI. C04B 35/468. Dielectric ceramics and electronic component / S. Sato (JP). Y. Terada (JP). Y. Fujikawa (JP); assignee TDK Corporation (JP). - Appl. No. 09/835.492; filed 17.04.2001; publicised 15.04.2003 - 28 p.

[40] Pat. 2002/0189402 A1 US. Int. CI.B22F 9/22. Nickel powder dispersion. method of producing nickel powder dispersion and method of producing conductive paste / T. Ito(JP). H. Takatori (JP). - Appl. No. 09/937.689; filed 28.09.2001; publicised 19.12.2002. - $12 \mathrm{p}$.

[41] Pat. 6.517.745 B2 US. Int. CI. H01B 1/02. Nickel powder and conductive paste / T. Hayashi (JP). Y. Yamaguchi (JP); assignee Mitsui Mining and Smelting Co., Ltd. (JP). - Appl. No. 09/793.133; filed 27.02.2001; publicised 11.02.2003. - 7 p.

[42] Pat. 7.618.474 B2 US. Int. CI. B22F 1/00 (2006.01). Nikel powder. conductive paste. and multilayer electronic component using same / Y. Akimoto. R. Nagashima. H. Ieda (JP); assignee Shoei Chemical Inc. (JP). - Appl. No. 11/602.062; filed 20.11.2006; publicised 17.11.2009. - 7 p.

[43] Pat. 2009/0032780 A1 US. Int. CI. H01B 1/02 (2006.01). Nickel paste / T. Suglyama (JP); assignee Noritake Co., Limited (JP). - Appl. No. 12/219.828; filed 29.07.2008; publicised 05.12.2009. - 9 p.

[44] Brodnyan, J.G., Gaskins, F.H. (1958) The rheology of various solutions of cellulose derivatives. J. of Rheol. Vol. 2. No 2. pp. 285 - 302. http://dx.doi.org/10.1122/1.548833

[45] Zhurkov, S. N. (1945): Investigation of the mechanism of polymers solidification. Proceedings of the first and second conferenced on highmolecular compounds. pp. 66 - 73. (in Russian).

[46] Barshteyn, R. S. - Kirilovich, V. I. - Nosovskiy, Yu. E. (1982): Plasticizers for polymers. Moscow. Chemistry. 197 p. (in Russian).

[47] Tager, A. A. (1978): Physical chemistry of polymers. Moscow. Chemistry.544p. (in Russian).
[48] Suslov, A. G. - Korsakova, I. M. (2010): Assigning, marking and controling of parameters of surface roughness of machines. Moscow.MSIU. 111 p. (in Russian).

[49] Tager, A. A. (1990): Some questions about polymers plasticizion. Plastichiskie massy. No 4. pp. 59-64. (in Russian).

[50] Prigogine, I. - Defey, R. (1966): Chemical thermodynamics. Novosibirsk. Science. 510 p. (in Russian).

[51] Tinius, K. (1964): Plasticizers. M.-L.,Khimiya. 916 p. (in Russian).

[52] Perepechko, I. I. (1978): Introduction in physics of polymers. Moscow, Khimiya. 310 p. (in Russian).

[53] Ikanina, T. V. - Suvorova, A. I. - Tager, A. A. (1986): About polymers antiplasticizion in high elastic state. Visokomol. Soedin. Vol. A28. No 4. pp. 817. (in Russian).

[54] Geles, I. S. (2007): Wood raw materials - a strategic framework and civilization reserve. Petrozavodsk. Karelian Research Centre of Russian Academy of Sciences. 499 p. (in Russian).

[55] Shtarkman, B. P. (1975): Plasticization of PVC. Moscow, Khimiya. 248 p. (in Russian).

[56] Baran, A. A. (1986): Polymer dispersions. Kiev, Naukova dumka. 204 p. (in Russian).

[57] Kozlov, P. V. - Papkov, S. P. (1982): Physico-chemical basis of plasticization of polymers. Moscow, Khimiya. 224 p. (in Russian).

[58] Lypatov, Yu. S. - Sergeeva, L. M. (1972): Plolymers adsorption. Kiev, Naukovadumka. 194 p. (in Russian).

[59] Lypatov, Yu. S. (1980): Interfacial phenomena in polymers. Kiev, Naukovadumka. 255 p. (in Russian).

[60] Severian, D. (2004): Polysaccharides: structural diversity and functional versatility. Second edition. CRC Press. $1224 \mathrm{p}$.

[61] O Sullivan, A. C. (1997): Cellulose: the structure slowly unravels. Cellulose. Vol. 4. No. 2. pp. 173 - 207. http://dx.doi.org/10.1023/A:1018431705579

[62] Kolpak, F. - Blackwell, J. (1976): Determination of the structure of Cellulose. Macromolecules. Vol. 9. No. 2. pp. 273 - 278. http://dx.doi.org/10.1021/ma60050a019

[63] Lovleva, M. M. - Papkov, S. V. (1982): Polymer crystallosolvates. Review. Polymer science. Vol. 24. No. 2. pp. 236 - 257. http://dx.doi.org/10.1016/0032-3950(82)90168-X

[64] Frey-Wyssling, A. (1954): The fine structure of cellulose microfibrils. Science. Vol. 119. No. 3081. pp. 80 - 81. http://dx.doi.org/10.1126/science.119.3081.80

[65] Sullivan, J. D. - Sachs, I. B. (1966): Research of cellulose morphology. Forest Product Journal. Vol. 16. No. 9. pp. 83 - 86.

[66] Schramm, G. (2003): A practical approach to rheology and rheometry. Gebrueder HAAKE GmbH. Karlsruhe. 312 p.

[67] Matvienko, V. N. - Kirsanov, E. A. (2011): Viscosity and structure of dispersed systems. Vestn. Mosk. Univ. Ser. 2. Chemistry. Vol. 52. No 4. pp. 243- 275.(in Russian).

[68] Efremov, I. Ph. (1982): Dilatancy of colloidal steuctures and polymer solutions. Uspekhikhimii. Vol. 2. No 2. pp. 285 - 304.(in Russian).

[69] Malkyn, A. Ya. - Isaev, A. I. (2007): Rheology: concepts. methods. and applications. Moscow, Khimiya. 560 p. (in Russian).

[70] Vinogradov, G. V. - Malkyn, A. Ya. (1977): Polymers rheology. Moscow, Khimiya. 453 p. (in Russian).

[71] Barnes, H. A. (2000): Handbook of elementary rheology. Institute of NonNewtonian Fluid Mechanics: University of Wales Aberystwyth. 200 p.

[72] Pivinskiy, Yu. E. (2001): Rheology of dilatant and thixotropical systems. Saint Petersburg. 174 p. (in Russian).

[73] Losev, I. P. - Trostyanskaya, E. B. (2012): Chemistry of syntetic polymers. Moscow. Kniga po trebovaniyu.610 p. (in Russian).

[74] Petropavlovskiy, G. A. (1988): Hydrophilic partially substituted cellulose ethers and their modification by chemical crosslinking. Leningrad, Nauka. 288 p. (in Russian).

[75] Im, D.-H. et al (2006): Preparation of Ni paste using binary powder mixture for thick film electrodes. Mater. Chem. Phys.,Vol. 96. pp. 228-233. http://dx.doi.org/10.1016/j.matchemphys.2005.07.047

$\underline{\text { Ref.: }}$

Umerova, Saide - Dulina, Iryna - Ragulya, Andrey: Rheology of plasticized polymer solutions

Építőanyag - Journal of Silicate Based and Composite Materials, Vol. 67, No. 4 (2015), 119-125. p.

http://dx.doi.org/10.14382/epitoanyag-jsbcm.2015.19 